\title{
The Evaluation of Estrogen Receptor $\beta$ as a Potential Prognosis Factor in Melanoma
}

\author{
CRISTINA BEIU1, MARIUS-NICOLAE POPESCU1,2*, MIHAI CRISTIAN DUMITRASCU1,3*, AIDA PETCA ${ }^{1,2}$, \\ CLAUDIA MEHEDINȚU ${ }^{1,4}$, PATRICIA DELIA FARCASANU ${ }^{1}$, RĂZVAN-COSMIN PETCA ${ }^{1,5}$, \\ CĂLIN CHIBELEAN ${ }^{6}$, FLORICA S,ANDRU ${ }^{1,2}$ \\ 1"Carol Davila" University of Medicine and Pharmacy, Eroii Sanitari Bvd., no. 8, 050474 Bucharest, Romania; \\ ${ }^{2}$ Elias University Emergency Hospital, Bvd. Marasti no. 17, 011461 Bucharest, Romania \\ ${ }^{3}$ University Emergency Hospital, Splaiul Independenței no.169, 050098 Bucharest, Romania \\ ${ }^{4}$ Malaxa Clinical Hospital, 12 Vergului Str., 022441, Bucharest, Romania \\ „5Prof. Th. Burghele” Clinical Hospital, 20 Panduri Str., 050653, Bucharest, Romania \\ ",George Emil Palade" University of Medicine, Pharmacy, Science and Technology of Târgu Mureș, 38 Gheorghe Marinescu \\ Str., 540139, Târgu Mureș, Romania
}

Differences across sexes in cutaneous melanoma incidence, metastatic pathways and disease outcome are consistently observed, with women having a significant survival advantage compared with men. This suggests that gender could play a role as a prognostic indicator through sex hormone signaling, but the mechanism is still unclear. This article focuses on available literature data concerning the influence of estrogen receptor beta (ER $\beta)$ expression as a host-related biological protective factor for female patients with melanoma. Furthermore, it highlights the potential role of estrogen receptor beta (ER $\beta)$ as a prognostic biologic marker in cutaneous melanoma.

Keywords: melanoma, sex, hormone receptors, estrogen receptor $\beta$

Malignant melanoma represents an important public health problem in terms of morbidity and mortality and its incidence is steadily increasing - NCI, 2012.

While tumor thickness (Breslow index), ulceration and presence of regional or distant metastasis at diagnosis are wellknown to be the most important prognostic determinants in melanoma [1], gender is now being discussed as a major factor associated with overall survival [2].

European and international studies showed that the largest sex differences for cancer survival occurred in melanoma and highlighted the hypothesis that biological sex differences could be an explanation [3,4]. The mechanism is still unclear but growing evidence show that sex hormone signaling is the cornerstone of the female melanoma protective effects [5,6].

This article reviews advances in our knowledge about sex as an independent prognosis factor in melanoma. We will explore the influence of estrogen receptor beta $(E R \beta)$ expression on the biological sex differences in melanoma.

\section{The sex bias of melanoma}

The Surveillance Epidemiology and End Result (SEER; http://seer.cancer.gov/statistics/) data about mortality and incidence for CMM in the United States revealed that in the past thirty years it was nearly double the prevalence in men compared to women [7].

As for the age-specific incidence, data collected and analyzed by SEER also pointed out gender differences. Rates were slightly higher in women aged 20-40 and decreased after the age of 45 years. Contrarily, striking differences were noticed in males, with a gradually increase after 45-50 years and an accelerated increase after the age of 50 - Figure 1.

Furthermore, significant differences have also been observed in the prognosis of melanoma in females vs. males. Among young individuals (15 - 39 years of age at diagnosis) - the only age group in which females had a higher incidence of melanoma - males continued to be associated with a lower survival rate [8-10].

It has been confirmed that in localized cutaneous melanoma (stage I or II) women have a far better prognosis in both disease progression and survival, after adjusting for the other well known prognosis factors [10]. More recent studies validated that the advantage is consistent in patients with advanced stage III and IV melanoma, tipping the balance in favor of the biologic factors as an underlying explanation [2].

*email: popescunm@gmail.com; Phone: +4072322781

drdumitrascu@yahoo.com; Phone: +40722223223

All the authors have equal contribution to this paper. 


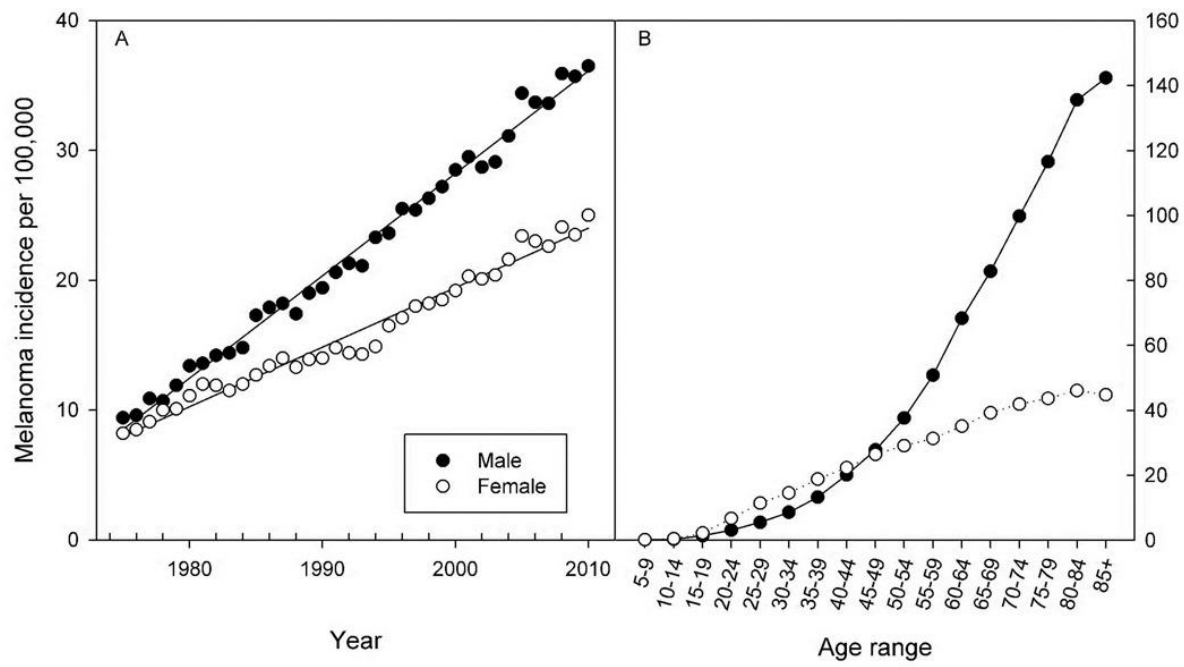

Fig. 1. SEER data for melanoma incidence in the U.S. population. The melanoma incidence per 100,000 individuals is shown for males (•) and females (०) in the U.S. In Panel A annual rates are shown from 1975 through 2010; in Panel B rates are shown as a function of age. Data were obtained from http://seer.cancer.gov/statistics/.

Sex disparities have also been noticed in a study in xiphophorus fish which expressed up-regulation of androgen levels after UVB exposure. The female vs. male melanoma incidence for UVB-exposed Xiphophorus is consistent with that seen in the human population, suggesting a sex-specific molecular genetic response [7]. Another study performed on Xiphophorus maculatus showed differences in the genetic perception of UVB in males and females, consistent with a twofold higher incidence of melanoma in males vs. females [11].

In line with this observation, various studies support a role for sex in contributing to the better survival rates among women (Table 1).

Table 1

LITERATURE STUDIES REPORTING FEMALE SURVIVAL ADVANTAGE

\begin{tabular}{|c|c|c|c|c|c|c|}
\hline Reference & Year & End Point & Country & $\begin{array}{c}\text { No. of } \\
\text { patients }\end{array}$ & $\begin{array}{c}\text { Adjusted Risk } \\
\text { Estimates }\end{array}$ & 95\% CI \\
\hline Balch et al & 2001 & DSS & United States & 13,581 & 0.84 & 0.76 to 0.92 \\
\hline de Vries et al & 2008 & RS & The Netherlands & 10,538 & $0.53^{\text {b)c }}$ & 0.48 to 0.61 \\
\hline Xing et al & 2010 & DSS & United States (SEER) & 37,519 & $0.67^{\text {c) }}$ & 0.60 to 0.75 \\
\hline Joose et al & 2011 & DSS & Germany & 117,374 & 0.62 & 0.56 to 0.70 \\
\hline Collins et al & 2011 & DSS ${ }^{\text {d) }}$ & United States (SEER) & 142,653 & $0.65^{\text {c) }}$ & 0.62 to 0.68 \\
\hline Thompson et al & 2011 & DSS & $\begin{array}{c}\text { International AJCC } \\
\text { Consortium }\end{array}$ & 10,233 & 0.69 & 0.61 to 0.79 \\
\hline
\end{tabular}

Abbreviations: AJCC - American Joint Committee on Cancer; DSS - disease-specific survival;

$\mathrm{RS}$ - relative survival (estimate of DSS).

a) Relative risk of women compared with men; presented as harzard ratio unless otherwise specified.

b) Presented as relative excess risk.

c) Value reported here is the inverse of the original risk estimate, because men were compared with women in the cited publication.

d) For patients who underwent surgery.

Table adapted from review article [12] discussing cutaneous melanoma in women co-written by article authors

\section{Hormones and melanoma}

It has been discussed that sex hormones deserve a spot in the multifactorial gender-related disparities in melanoma. Furthermore, hormone-related therapeutic possibilities have been taken into account and their antimelanoma effect is yet a controversy. While melanoma is classically considered a non-hormone -related cancer, mounting evidence suggest a direct correlation between estrogen levels and melanoma outcome [13-15].

The biological effects of estrogens are mediated through two ER subtypes, ER $\alpha$ and ER $\beta$, members of the nuclear steroid hormone receptor superfamily [16]. The balance between this two subtypes expression is essential in the estrogen signaling. These receptors bind to 17- $\beta$-estradiol and control certain genes expression through specific DNA sequences [17-19]. 
It has been showed that both benign and malignant melanocytic lesions are positive for ER $\beta$, but not for ER $\alpha$, which seems to be very rarely expressed in the skin [20-21]. In line with this observation, various studies support a role for ER $\beta$ in contributing to the better survival rates among women $[22,23]$.

It is well known that ER $\alpha$ and ER $\beta$ have different biological functions, according to their tissue-specific action [24-28]. Increasing evidence show a promotion of cancer progression through perturbed estrogen signaling. The differential expression of ER $\alpha$ and ER $\beta$ in cancer cells supports the concept that the two ER subtypes have contrasting functions in the essential fundamentals of cancer biology [29].

ER $\alpha$ promotes carcinogenesis due to its pro-proliferation properties, while ER $\beta$ has a protective role against skin tumor growth. In such a way, that both natural and non-natural synthetic ER $\beta$ ligands may inhibit tumorigenesis either by activating ER $\beta$ or by suppressing the tumor activity of ER $\alpha$ through heterodimers formations which is highly increased by the presence of the ligands [24-26] - Figure 2.

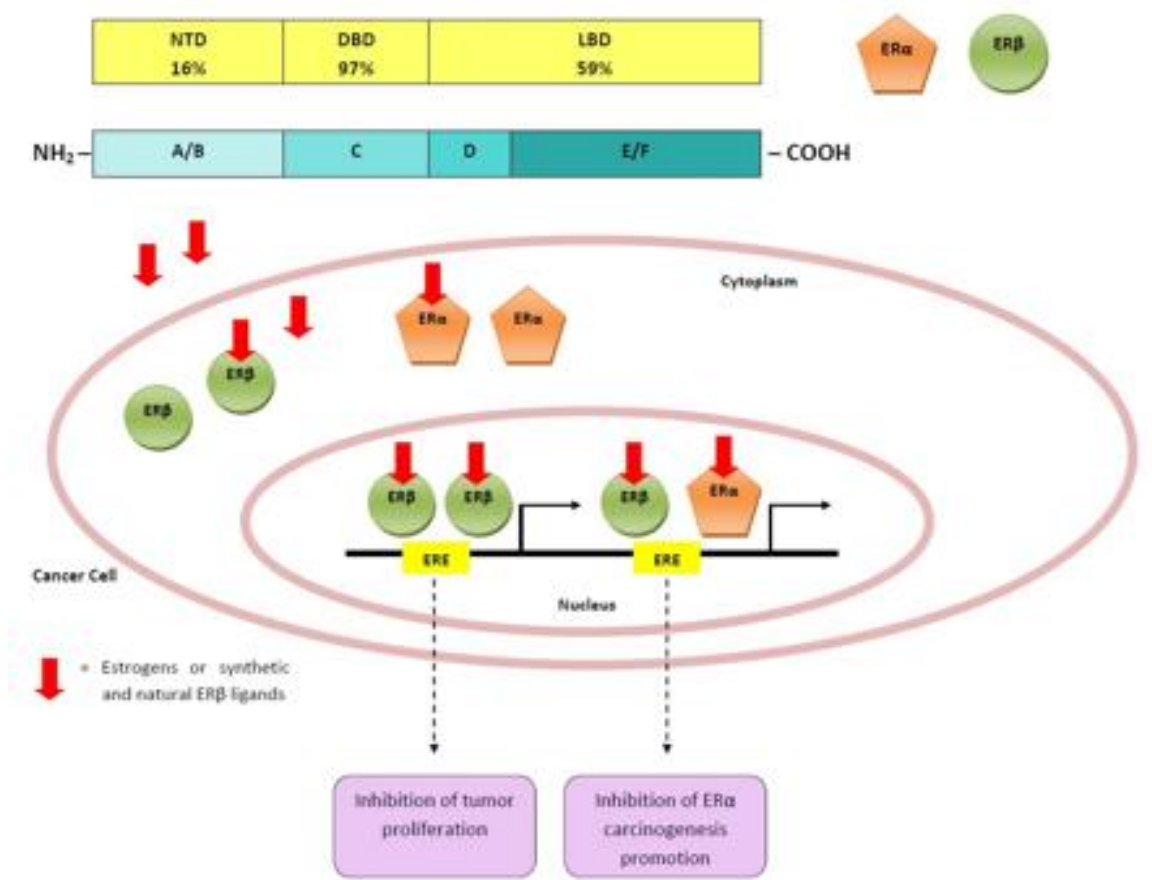

Fig. 2. Schematic design of the molecular mechanisms of ER $\beta$ activation on tumor growth. In tumor cells expressing both $\mathrm{ER} \beta$ and $\mathrm{ER} \alpha, \mathrm{ER} \beta$ ligands can either induce ER $\beta$ :ER $\beta$ homodimers, inhibiting tumor proliferation or ER $\beta: E R \alpha$ heterodimers, inhibiting carcinogenesis promotion

\section{Correlations between ER $\beta$ expression in the tumoral microenvironment and melanoma progression}

De Georgi et al. showed that ER $\beta$ expression in melanoma cells is reduced compared with perilesional healthy skin [30].

Furthermore, supporting the role for ERs in melanoma outcome, the loss of of ER $\beta$ protein levels was found to be directly proportional to Breslow thickness - its most important prognostic factor - and this reduction in ER $\beta$ resulted in more aggressive melanoma. ER $\beta$ expression levels were lower in metastatic melanomas than in non-metastatic lesions. Also, consistent with gender differences in melanoma prognosis, men showed lower levels of ER $\beta$ than woman in both tumoral and healthy tissues [31].

Kanda and Watanabe [32] reported that following incubation of the 17-beta-isomer of estradiol, metastatic melanoma cells growth was inhibited in vitro, by inhibiting the production of interleukin-8. This effect was neutralized by exogenously added IL-8 and was only observed in ER-positive human melanoma cells, indicating a receptor-dependent manner of inhibiting melanoma cell growth.

As a possible mechanism for the female survival benefit, Richardson et al. [33] and Roy et al. [34] noted that the main estrogenic hormone, 17 beta-estradiol, repressed human melanoma cells invasiveness, but the antitumoral effect was inconsistent after syngeneic B16 tumors transplantation in C57BL/6 mice.

Cho et al. [35] used a mouse melanoma skin cancer model to assess the protective role of ER $\beta$ against tumor growth. They showed that implanted B16 murine melanoma cells grew faster in mice lacking ER $\beta$ (suppression of ER $\beta$ signaling via ER $\beta$ knockout) in comparison to congenic C56BL/6 mice with unharmed ER $\beta$.

In a more recent paper, ER $\beta$ expression has also been shown to be down-regulated in invasive melanomas, with sentinel lymph node metastasis, suggesting its potential efficacy as an immunohistochemical marker for metastatic potential and poor outcome in malignant melanomas [36]. 
Contradictory results come from Tellez et. al who recently performed retrospective analysis of 420 women under the age of 50 and reported the following: an increased risk of mortality, recurrence, and metastasis in pregnancy-associated melanoma and lower survival rates associated with higher incidence of sentinel lymph node metastasis in woman aged 40 to 49 years old. One of the author's several explanations for this results was the adverse effects of high serum estrogen levels [37]. In response to this emerging evidence, Gori. et al tried to find a surrogate etiopathogenetic explanation, stating that the loss of ER $\beta$ expression with age and pregnancy may explain a more poor outcome in melanoma [38].

It was also recently demonstrated that $\mathrm{ER} \beta$, and not $\mathrm{ER} \alpha$, is the predominant subtype expressed in a group of various melanoma cell lines harboring distinct genetic mutations (A375, BLM, WM115, and WM1552) [39]. Expression pattern of the ER $\beta$ isoforms was comparable in BLM (harboring the NRAS, but not the BRAF mutation) and WM115 (BRAF V600Dmutant) melanoma cells: decreased expressions of ER $\beta 1$ and ER $\beta 5$ were found to be at similar levels whereas ER $\beta 2$ exhibited an increased level of expression. Contrarily, both ER $\beta 2$ and ER $\beta 5$ were expressed at higher levels than ER $\beta 1$ in A375 (BRAF V600E-mutant) cells [39].

Taken together, these studies indicate that there is indeed a potential role of ER $\beta$ as a prognostic marker of melanoma and the loss of its expression may promote tumor growth.

\section{Conclusions}

Overall, the correlation between estrogen receptors and the prognosis of cutaneous melanoma is still intriguing and controversial. In line with the better outcome of women compared to men and with clinical data demonstrating a hormonallydependent melanoma course, we hypothesize that the female advantage is associated with biological characteristics of the host, independently of the other key prognostic factors. Large-scale studies will ultimately be required to elucidate the potential role of ER $\beta$ expression as a prognostic marker of melanoma and detecting ER $\beta$ expression could become a useful tool for the clinicians in monitoring melanoma patients. Further understanding of the estrogen-dependent regulation of melanoma cells through stimulation of ER $\beta$ receptors could even serve as a starting point in unraveling new ways to trigger anti-tumor hormonal responses in melanoma patients.

\section{References}

1.SCOLYER, R.A., JUDGE, M.J., EVANS, A., FRISHBERG, D.P., PRIETO, V.G., THOMPSON, J.F., et al. Am J Surg Pathol., 37, no. 12, 2013, p.1797.

2.JOOSSE, A., COLLETTE, S., SUCIU, S., NIJSTEN, T., PATEL, P.M., KEILHOLZ, U., et al. J. Clin. Oncol., 31, no. 18, 2013 , p. 2337.

3.MICHELI, A., CIAMPICHINI, R., OBERAIGNER, W., CICCOLALLO, L., DE VRIES, E., IZARZUGAZA, I., et al. Eur. J. Cancer., 45, no.6, 2009, p.1017.

4.COOK, M.B., MCGLYNN, K.A., DEVESA, S.S., FREEDMAN, N.D., ANDERSON, W.F. Cancer Epidemiol. Biomarkers Prev., 20, no.8, 2011, p. 1629.

5.NATALE, C.A., LI, J., ZHANG, J., DAHAL, A., DENTCHEV, T., STANGER, B.Z. et al. Elife., 7, 2018, pii. e31770

6.MEHEDINTU, C., BRATILA, E., CIRSTOIU, M., PETCA, A., BRINDUSE, L. A., et al. Rev. Chim.(Bucharest), 70, no. 7, 2019 , p. 2375.

7.MITCHELL, D.L., FERNANDEZ, A.A., GARCIA, R., PANIKER, L., LIN, K., HANNINEN, A., et al. Pigment Cell Melanoma Res., 27, no. 3, 2014, p.408

8.GAMBA, C.S., CLARKE, C.A., KEEGAN, T.H., TAO, L., SWETTER, S.M. JAMA Dermatol., 149, no. 8, 2013 , p. 912.

9.JOOSSE, A., DE VRIES, E., ECKEL, R., NIJSTEN, T., EGGERMONT, A.M., HOLZEL, D., et al. J. Invest. Dermatol., 131, no. 3, 2011 , p.719. 10.JOOSSE, A., COLLETTE, S., SUCIU, S., NIJSTEN, T., LEJEUNE, F., KLEEBERG, U.R., et al. J. Clin. Oncol., 30, no. 18, 2012 , p. 2240.

11.BOSWELL, W., BOSWELL, M., TITUS, J., SAVAGE, M., LU, Y., SHEN, J., et al. Comp. Biochem. Physiol. C. Toxicol. Pharmacol., 178, 2015, p. 76 .

12.ROH, M.R., ELIADES, P., GUPTA, S., GRANT-KELS, J.M., TSAO, H. Int. J. Womens Dermatol., Volume 3, Issue 1, Supplement, 2017 , p. 11. 13.MITKOV, M., JOSEPH, R., COPLAND, J. $3^{\text {RD }}$ Mol. Cell. Endocrinol., 417, 2015, p. 94.

14.ETCA, A., PETCA, R. C., ZVANCA, M., MARU, N., MASTALIER, B., DOGAROIU, C. Rom. J. Leg. Med, 27, no. 1, 2019 , p. 43. 15.JANIK, M.E., BELKOT, K., PRZYBYLO, M. Contemp. Oncol. (Pozn), 18, no. 5, 2014, p. 302.

16.DE GIORGI, V., GORI, A., ALFAIOLI, B., PAPI, F., GRAZZINI, M., ROSSARI, S., et al. J. Clin. Oncol., 29, no. 4, 2011 , p. 94.

17.NILSSON, S., KOEHLER, K.F., GUSTAFSSON, J.A. Nat. Rev. Drug. Discov., 10, no. 10, 2011, p. 778.

18.NILSSON, S., GUSTAFSSON, J.A. Clin. Pharmacol. Ther., 89, no.1, 2011, p. 44.

19.PETCA, A., RADU, D. C., PETCA, R. C., MEHEDINTU, C., BARAC, R. I., et al. Rev. Chim.(Bucharest), 70, no. 6, 2019 , p. 2021.

20.OHATA, C., TADOKORO, T., ITAMI, S. J Dermatol., 35, no. 4, 2008, p. 215.

21.SCHMIDT, A.N., NANNEY, L.B., BOYD, A.S., KING, L.E., JR., ELLIS, D.L. Exp. Dermatol., 15, no. 12, 2006 , p. 971.

22.ZGURA, A., GALES, L., HAINEALA, A. B., BRATILA, E., MEHEDINTU, C., et al. Rev. Chim.(Bucharest), 70, no. 7, 2019 , p. 2362.

23.RUSU, M. C., POP, F., HOSTIUC, S., MANTA, L., MARU, N., GRIGORIU, M. Rom. J. Morphol. Embryol., 59, no. 3, 2018 , p. 663.

24.JIA, M., DAHLMAN-WRIGHT, K., GUSTAFSSON, J.A. Best Pract. Res. Clin. Endocrinol. Metab., 29, no. 4, 2015 , p. 557.

25.DEY, P., BARROS, R.P., WARNER, M., STROM, A., GUSTAFSSON, J.A. J. Mol. Endocrinol., 51, no. 3, 2013 , p. 61.

26.BOTTNER, M., THELEN, P., JARRY, H., J. Steroid Biochem. Mol. Biol., 139, 2014, p. 245.

27.ECHIM, G., PISOSCHI, C. G., VARI, C. E., KOLCSAR, M., OSZ, B. E., et al. Farmacia, 64, no. 3, 2016 , p. 358.

28.PADURARU, D. N., BOUARIU, A., ION, D., DUMITRASCU, M. C., NITIPIR, C., et al. Rom. Biotechnol. Lett., 23, no. 5, 2018 , p. 14056. 29.PRODEA, M. C., SANDRU, F., CARPENCO, E., GAJE, P. N., HORHAT, I. D., et al. Rev. Chim.(Bucharest), 70, no. 5, 2019 , p. 1863.

30DE GIORGI, V., MAVILIA, C., MASSI, D., GOZZINI, A., ARAGONA, P., TANINI, A., et al. Arch. Dermatol., 145, no. 1, 2009 , p. 30. 31DE GIORGI, V., GORI, A., GANDINI, S., PAPI, F., GRAZZINI, M., ROSSARI, S., et al. Br. J. Dermatol., 168, no.1, 2013 , p. 513.

32.KANDA, N., WATANABE, S. J. Invest. Dermatol., 117, no. 2, 2001, p. 274. 
33.RICHARDSON, B., PRICE, A., WAGNER, M., WILLIAMS, V., LORIGAN, P., BROWNE, S., et al. Br. J. Cancer., 80, no. 12, 1999 , p. 2025. 34.ROY, S., REDDY, B.S., SUDHAKAR, G., KUMAR, J.M., BANERJEE, R., Mol. Pharm., 8, no. 2, 2011 , p. 350.

35.CHO, J.L., ALLANSON, M., REEVE, V.E., Photochem. Photobiol. Sci., 9, no. 4, 2010, p. 608.

36.SPYROPOULOS, C., MELACHRINOU, M., VASILAKOS, P., TZORAKOLEFTHERAKIS, E., Eur. J. Gynaecol. Oncol., 36, no. 2 , 2015 , p. 123. 37.TELLEZ, A., RUEDA, S., CONIC, R.Z., POWERS, K., GALDYN, I., MESINKOVSKA, N.A., et al. J. Am. Acad. Dermatol., 74, no. 4, 2016, p. 731.

38.ORI, A., SAVARESE, I., D'ERRICO, A., GRAZZINI, M., PAPI, F., MAIO, V., et al. J. Am. Acad. Dermatol., 75, no. 3, 2016 , e117.

39MARZAGALLI, M., CASATI, L., MORETTI, R.M., MONTAGNANI MARELLI M., LIMONTA P. PLoS One, 10, no. 7, 2015, e0134396

Manuscript received: 23.09 .2019 